\title{
Life History and Geographical Patterns of Growth in Capelin, Mallotus villosus, of the Labrador and Newfoundland Areas
}

\author{
G. H. Winters \\ Department of Fisheries and Oceans, Fisheries Research Branch \\ Northwest Atlantic Fisheries Centre, P. O. Box 5667 \\ St. John's, Newfoundland, Canada A1C 5X1
}

\begin{abstract}
Growth patterns of capelin, Mallotus villosus, in the Labrador-Newfoundland region were examined on the basis of backcalculated estimates of fish length from otolith measurements. The occurrence of Lee's phenomenon and growth compensation as a characteristic feature of capelin growth is attributed to differential spawning mortality between the faster-growing and slowergrowing individuals of a year-class. A progressive increase in growth of capelin occurs from the northern to the southern parts of their distribution in the region, and this cline is attributed to differences in timing of the spawning season and the inter-related effects on the age at maturity.
\end{abstract}

\section{Introduction}

Research on capelin in the Northwest Atlantic has tended to be intermittent and restricted to the Newfoundland area, due to its relatively minor importance as a commercial species. Among the most notable studies are those by Jeffers (MS 1931) who dealt mainly with larval development, Sleggs (1933) who concentrated on its economic biology, Templeman (1948) who elucidated various aspects of its life history, and Pitt (1958a, 1958b) who provided information on age, growth, distribution, spawning and racial aspects of capelin. More recent studies on capelin are those of Winters and Carscadden (1978), Carscadden and Misra (1980), and Frank and Leggett (1981). Although the growth of capelin in inshore Newfoundland waters and on the Grand Bank has been described by Templeman (1948) and Pitt (1958a) respectively, there has been no comparison of growth rates of capelin from other areas of its range off eastern Canada. In view of the development of commercial fisheries for capelin during the past decade and the need for more recent information on biological characteristics, this paper presents new data on variations in growth of capelin in the Newfoundland and Labrador areas.

During 1966-72, samples containing mainly mature or maturing capelin were obtained from a wide range of localities at different times of the year. Comparison of growth curves for the different areas, based on length at capture, would give biased results due to the differing amounts of new (current year) growth in the fish taken at different times of the year. This difficulty was overcome by utilizing the back-calculation technique which not only provides estimates of growth for the earilier age-groups but also defines the period of growth for comparative purposes.
The back-calculation technique has normally been applied to scale measurements, but the first growth ring is usually missing in capelin scales (Templeman, 1948) and the annuli are not well-defined. Consequently, otoliths were selected for measurement. Back-calculation of capelin growth from otolith mesurements has been carried out by Templeman $(1948,1968)$ for the Newfoundland area, and by Prokhorov (1965) and Monstad and Gjosaeter (MS 1977) for the Barents Sea. Templeman (1948) measured otolith widths but did not establish the form of the otolith width-fish length relationship. Instead, he backcalculated fish lengths at age from direct otolith widthfish length ratios. Templeman (1968) determined that the otolith width-fish length relationship was in the form of two straight lines which he used to backcalculate capelin lengths. However, he did not separate the sexes or areas in determining the form of the otolith width fish length relationship. Prokhorov (1965) measured otolith radii and found that the otolith radius-fish length relationship in capelin was an irregular curve which was different for each sex. Similar results were obtained by Monstad and Gjosaeter (MS 1977).

\section{Materials and Methods}

\section{Source of samples}

The samples (Table 1) were obtained from widely distributed localities along the coasts of Labrador and eastern and southern Newfoundland and from the Grand Bank (Fig. 1). Beach-spawning capelin from Pack's Harbour, Outer Cove and Grand Beach were caught by small-meshed $(10-20 \mathrm{~mm})$ castnets. The Pack's Harbour sample was taken during the middle of the spawning season (late June to mid-July), whereas 


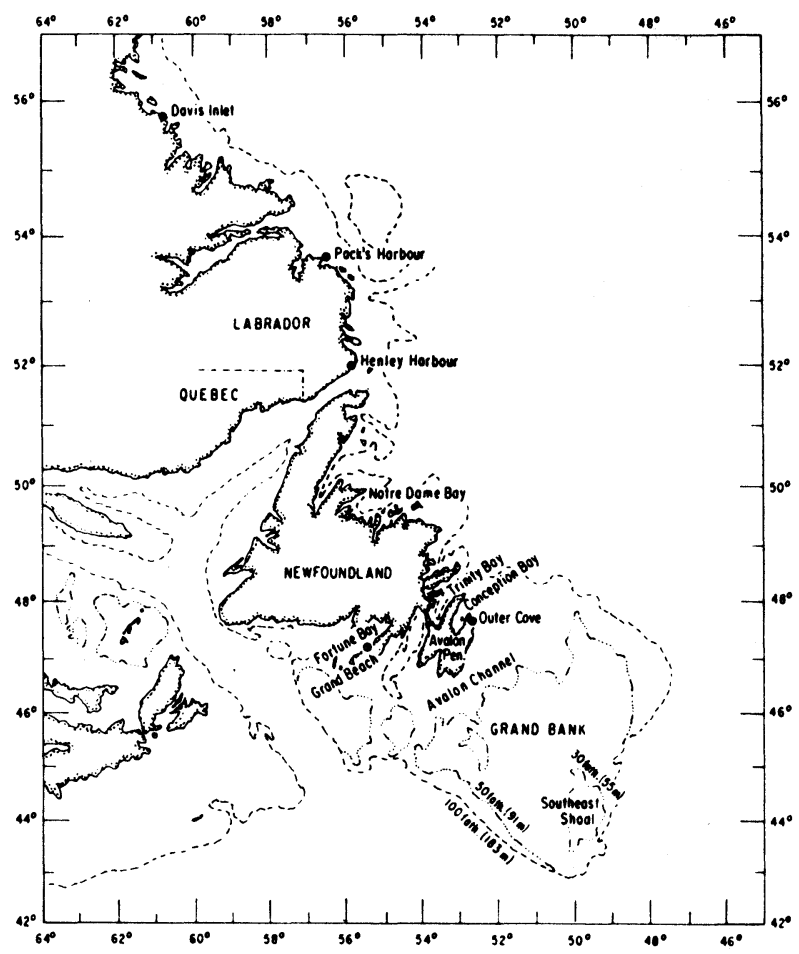

Fig. 1. Areas and place names mentioned in the text

TABLE 1. Numbers of capelin in samples from various localities of the Labrador-Newfoundland region (see Fig. 1).

\begin{tabular}{llrrr}
\hline \hline \multicolumn{1}{c}{ Locality } & $\begin{array}{c}\text { Month and year } \\
\text { of sampling }\end{array}$ & Male & Female & Total \\
\hline Davis Inlet & Jul 1966 & 38 & 75 & 113 \\
Pack's Harbour & Jul 1966, 1967 & 99 & 100 & 199 \\
Henley Harbour & Jul 1968 & 92 & 94 & 186 \\
Notre Dame Bay & Nov 1972 & 38 & 59 & 97 \\
Trinity Bay & Mar-Jun 1967 & 468 & 425 & $969^{\text {a }}$ \\
Outer Cove & Jun-Jul 1967 & 483 & 212 & 695 \\
Grand Beach & Jun-Jul 1966 & 120 & 93 & 213 \\
Grand Bank & Jun-Aug 1967 & 287 & 358 & 645 \\
\hline
\end{tabular}

${ }^{a}$ Includes 76 unsexed capelin.

those from Outer Cove and Grand Beach were obtained throughout the spawning season (mid-June to early July). Pre-spawning and spent capelin from the Southeast Shoal of the Grand Bank were caught by otter trawl with liners of 10-30 mm (stretched) mesh in the codend. The samples from Trinity Bay included immature capelin taken by midwater trawl with a 10 $\mathrm{mm}$ codend liner and pre-spawning capelin taken by otter trawl with a $30 \mathrm{~mm}$ codend liner. Gillnets with mesh sizes ranging from 20 to $40 \mathrm{~mm}$ were used to catch spawning capelin in Trinity Bay. The Notre Dame Bay samples were kindly provided by scientists of the USSR research vessel Persey III.

\section{Methods of fish measurement}

Length measurements of capelin were taken as total lengths $(\mathrm{mm})$ from the tip of the mandible to the

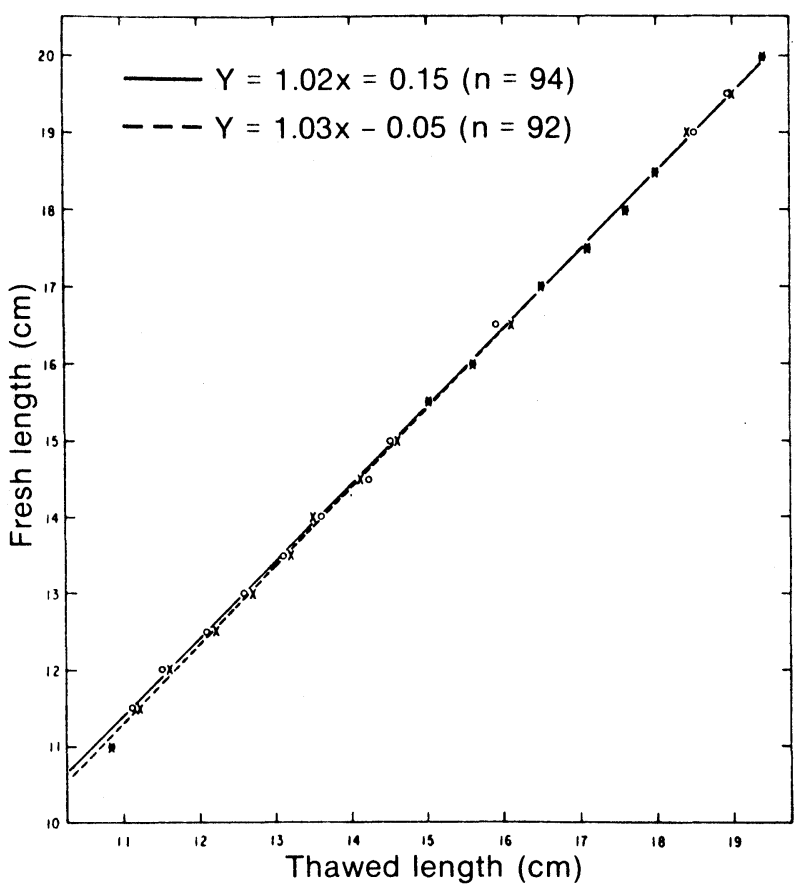

Fig. 2. Regression lines for lengths of fresh capelin on lengths after thawing of speciments frozen in sea-water and dry.

end of the ventral lobe of the caudal fin deflected posteriorly in line with the body (Templeman, 1948). Because many of the samples were frozen, either dry or in sea-water, it was necessary to determine shrinkage factors for conversion of thawed length measurements to fresh lengths. Approximately 100 capelin in each of two samples were measured in the fresh condition, tagged for subsequent identification and frozen in two plastic bags, one containing sea-water and the other without water. After one week, the fish were thawed and measured again by the same person. The regression lines (Fig. 2) show very little difference in shrinkage between the capelin frozen in sea-water and without sea-water. The shrinkage over the length range of fish in the samples was approximately $3 \%$, and this factor was used to convert thawed lengths to fresh lengths. Lengths of capelin preserved in $95 \%$ alcohol were increased by $5 \%$ (Winters, MS 1966).

\section{Age determination and growth measurements}

For age determination, a stereoscopic model SMZ Nikon microscope with a micrometer in one eyepiece was used to examine the otoliths, which were placed in a black watch-glass and immersed in 95\% isopropyl alcohol. Ages were determined from the lateral convex face of the otoliths by two methods, the main one utilizing the alternating opaque (summer) and translucent (winter) zones, and the corroborating one utilizing the ridge and groove technique, as described by Templeman (1948). The individuals were assigned to age-groups according to the sampling date in relation 
to the arbitrarily designated birthdate (1 January). Otoliths with poorly defined annuli $(<2 \%)$ were not used for ageing.

Otolith radii were measured instead of otolith widths because radii are easier to measure and also because new growth tends to appear first at the ventral edge of the otolith, particularly in older fish. Following alignment of the otolith in a line $(A B)$ extending from the rostrum to the center of the nucleus (Fig. 3), the radius to the outside edge of each winter zone was measured along line $\mathrm{BC}$ at right angle to $\mathrm{AB}$. The otolith radii were recorded in terms of eyepiece units (1 $\mathrm{mm}=26.5$ EPU). All otoliths with abnormal shapes $(<1 \%)$ were not measured.

The length-at-age data were analyzed according to the von Bertalanffy (1938) growth equation

$$
L_{t}=L_{\infty}\left\{1-e^{-K\left(t-t_{0}\right)}\right\}
$$

where $L_{t}$ is the mean length $(\mathrm{mm})$ at age $t$ (years), $L_{\infty}$ is the asymptotic length $(\mathrm{mm}), \mathrm{t}_{\mathrm{o}}$ is the theoretical age at zero length, and $\mathrm{K}$ is the growth coefficient.

\section{Results}

\section{Relation of otolith radius to fish length}

All ages and maturity stages for both sexes were represented in teh capelin samples from Trinity Bay. Consequently, the data for this area were selected for use in describing the relationship between otolith radius and total length of capelin, subsequently termed the "otolith-body relationship".

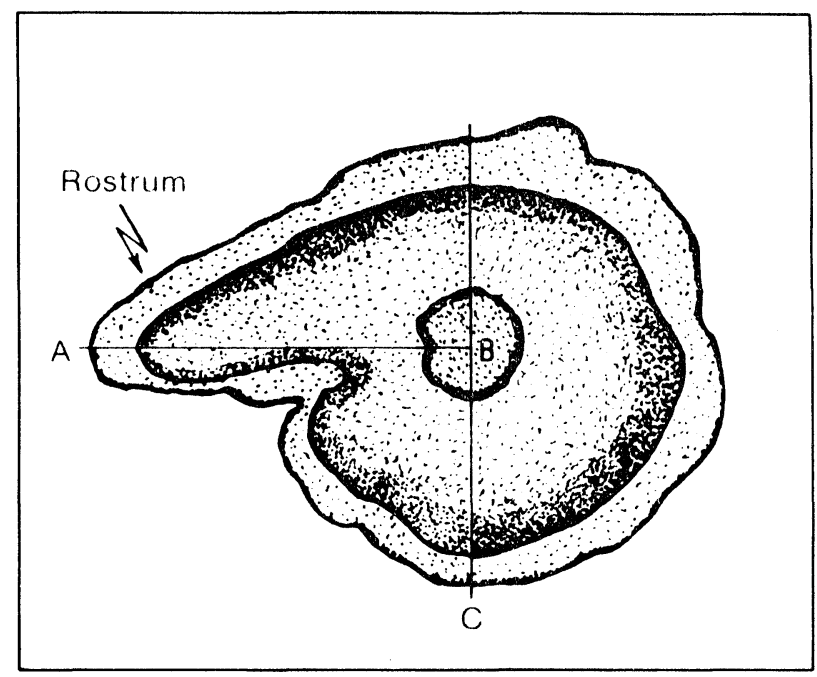

Fig. 3. Sketch of capelin otolith showing the axis $(A B)$ of radius measurement.
The increasing disparity in size between sexes after the first year of life (Templeman, 1948; Pitt, 1958a) necessitated determining an otolith-body relationship for each sex in capelin aged 2 years and older. The otolith-radii measurements were grouped in 0.5 EPU intervals, and the average body lengths $(\mathrm{mm})$ were plotted at the mid-point of each 0.5 EPU interval (Fig. 4). The otolith-body relationship for each sex is in the form of an irregular curve. The shapes of the curves for males and females are similar to those reported by Prokhorov (1965) for Barents Sea capelin. The inflexion points at $165 \mathrm{~mm}$ for males and $150 \mathrm{~mm}$ for females correspond to the approximate average size at maturity (Carscadden, 1978). Templeman (1968) noted that the intersection point of two straight lines, which he used to describe the relationship between otolith width and total length of capelin corresponded to the approximate size at maturity.

Various transformations of the data failed to produce an otolith-body relationship amenable to convenient mathematical description. Consequently, back-calculation of body lengths from otoliths annuli measurements was carried out by estimating fish lengths corresponding to otolith radii from the empirical curves of Fig. 4.

\section{Age-length relationships}

For each age-group of Trinity Bay capelin, lengths were back-calculated from otolith radii measurements to the outer edge of the last winter zone, averaged and plotted against age for males and females (Fig. 5A, Table 2). Comparison of the growth curves for capelin

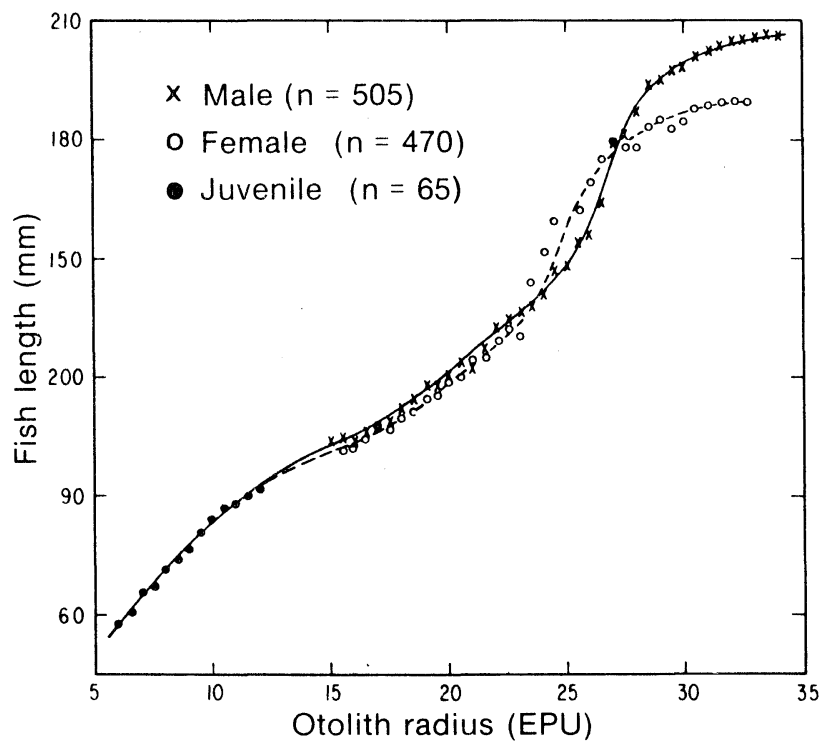

Fig. 4. Relationships between fish length and otolith radius for capelin from Trinity Bay. 
TABLE 2. Mean lengths at age of capelin from Trinity Bay, 1967, back-calculated from the empirical curves shown in Fig. 4.

\begin{tabular}{|c|c|c|c|c|c|c|c|c|c|c|c|}
\hline \multirow{2}{*}{$\begin{array}{l}\text { Age at } \\
\text { capture } \\
(y r)\end{array}$} & \multirow[b]{2}{*}{ Sex } & \multirow[b]{2}{*}{ Maturity } & \multirow{2}{*}{$\begin{array}{l}\text { No. of } \\
\text { fish }\end{array}$} & \multirow{2}{*}{$\begin{array}{c}\text { Mean length } \\
\text { at capture } \\
(\mathrm{mm})\end{array}$} & \multicolumn{7}{|c|}{ Computed mean lengths $(\mathrm{mm})$ at age } \\
\hline & & & & & & 1 & 2 & 3 & 4 & 5 & 6 \\
\hline 1 & Juv. & Immature & 76 & 78 & & 73 & & & & & \\
\hline \multirow[t]{2}{*}{2} & $M$ & Immature & 82 & 115 & & 76 & 115 & & & & \\
\hline & $\mathrm{F}$ & " & 150 & 112 & & 74 & 111 & & & & \\
\hline \multirow[t]{2}{*}{3} & M & Immature & 52 & 141 & & 70 & 112 & 141 & & & \\
\hline & $\mathrm{F}$ & " & 25 & 127 & & 68 & 103 & 124 & & & \\
\hline \multirow[t]{2}{*}{3} & $M$ & Mature & 77 & 187 & & 81 & 131 & 186 & & & \\
\hline & $F$ & $"$ & 43 & 159 & & 78 & 117 & 155 & & & \\
\hline \multirow[t]{2}{*}{4} & $M$ & Mature & 176 & 201 & & 76 & 118 & 170 & 200 & & \\
\hline & $\mathrm{F}$ & Mature & 61 & 180 & & 74 & 110 & 158 & 180 & & \\
\hline \multirow[t]{2}{*}{5} & M & Mature & 76 & 203 & & 69 & 111 & 137 & 183 & 203 & \\
\hline & $\mathrm{F}$ & & 141 & 184 & & 70 & 107 & 130 & 173 & 183 & \\
\hline \multirow[t]{2}{*}{6} & M & Mature & 5 & 205 & & 66 & 109 & 133 & 178 & 201 & 205 \\
\hline & $\mathrm{F}$ & 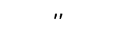 & 5 & 184 & & 67 & 99 & 117 & 150 & 177 & 184 \\
\hline \multirow{2}{*}{\multicolumn{5}{|c|}{ Averages of back-calculated lengths (mm) }} & M & 74 & 118 & 162 & 194 & 202 & 205 \\
\hline & & & & & $\mathrm{F}$ & 72 & 109 & 139 & 174 & 183 & 184 \\
\hline
\end{tabular}

which are mature at age 3 indicates that greater acceleration in growth of males relative to females after age 1 produces a maximum size disparity of $30 \mathrm{~mm}$ at age 3 , after which the size difference declines to approximately $20 \mathrm{~mm}$. Immature capelin at age 3 are considerably smaller than mature capelin of the same age, the difference being in excess of $40 \mathrm{~mm}$ for males and 30 $\mathrm{mm}$ for females.

Age-length relationships of capelin were also derived by averaging all back-calculated lengths at each age (Fig. 5B). These relationships are based on the average of the former sizes of those fish which had survived to the sampling age and, according to Ricker (1969), are more representative of the growth than curves based on length-at-age capture. The size disparity between sexes increases to a maximum of 23 $\mathrm{mm}$ at age 3 and decreases slightly thereafter (Fig. 5B).

\section{Growth patterns of successive age-groups}

The plots of back-calculated lengths for agegroups 3-6 (Table 2) against age for male and female capelin from Trinity Bay (Fig. 6) indicate initial divergence in growth up to age 3 , followed by an apparent convergence. According to Zamakhaev (1965), this initial divergence and subsequent convergence of the curves for successive age-groups are characteristic of Lee's phenomenon of apparent change in growth rate with age in its typical form. Comparison of backcalculated lengths for age-groups 1-6 (Table 2) indicates that Lee's phenomenon is clearly present at all ages for mature fish but is not well defined for immature fish. Inasmuch as capelin that are immature at age 3 must mature at some older age, it is clear that they also must show Lee's phenomenon because they are smaller than mature 3-year-olds at successive ages.

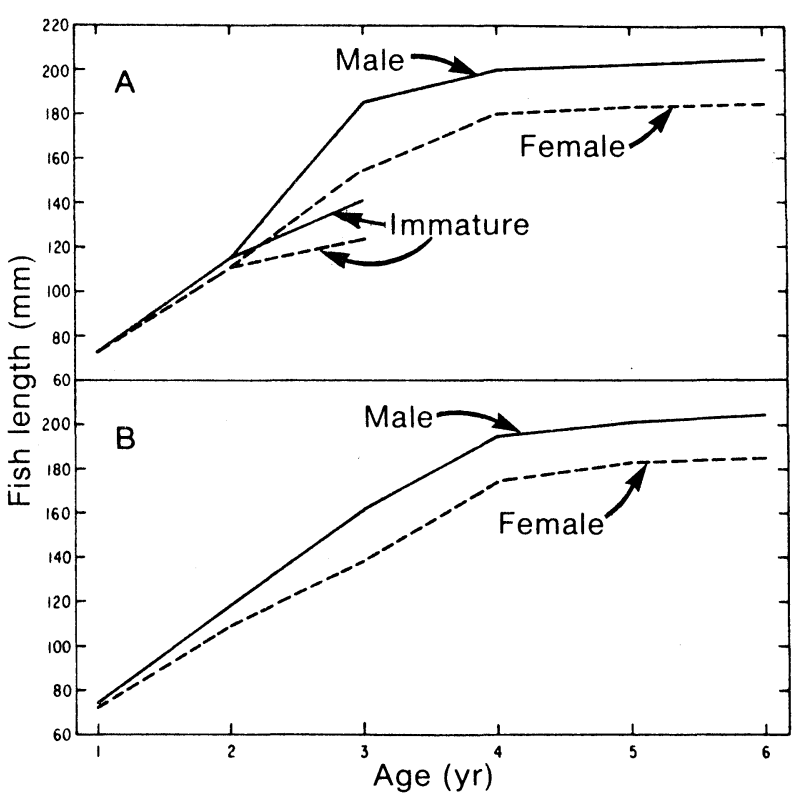

Fig. 5. Growth patterns of capelin from Trinity Bay: (A) average lengths at age of capture back-calculated to the edge of the last winter zone; (B) average lengths back-calculated to the edge of winter zones representing particular ages.

The later convergence of the initially diverging growth curves (Fig. 6) may sometimes be regarded as a phenomenon of growth compensation between successive age-groups (Zamakhaev, 1965). Arrangement of the back-calculated lengths at age $1\left(l_{1}\right)$ for agegroups 4 and 5 by increasing size and comparison of the subsequent length increments at age (Table 3) indicate distinct growth compensation for both males and females during the second year, in that the length increments decline with increasing $l_{1}$ values. This pattern is reversed in the third year, which corresponds to 


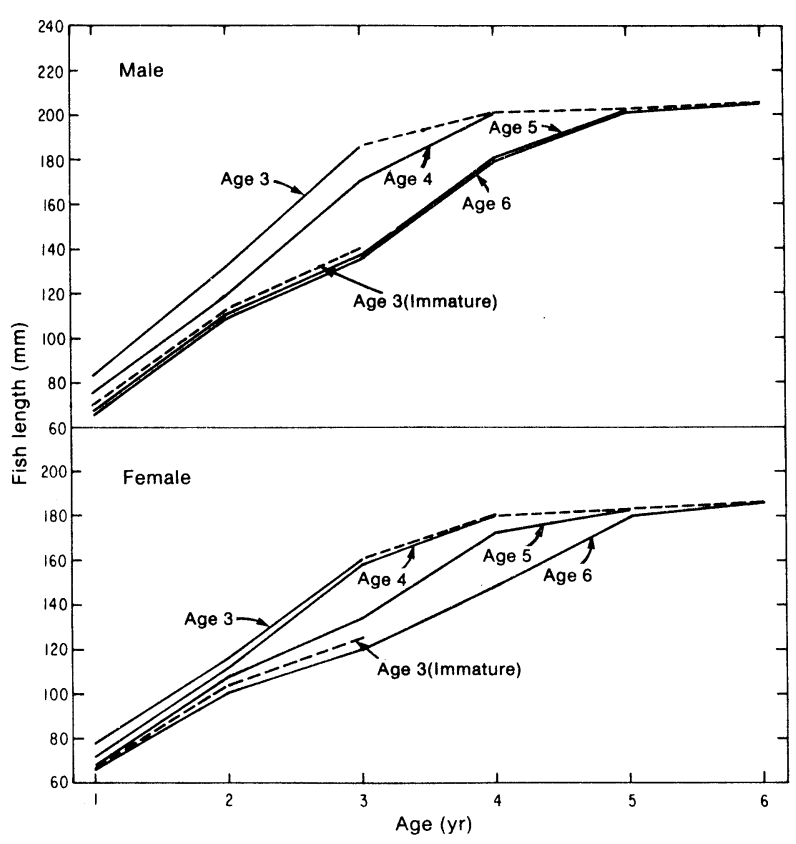

Fig. 6. Growth patterns of successive age-groups of capelin from Trinity Bay derived from back-calculated lengths.

the age of maximum size difference between mature and immature capelin, as shown in Fig. 6. However, growth compensation is again evident in the fourth year, with the result that the range of final sizes at age 4 is considerably less than the range of $I_{1}$ values.

For age-group 5, growth compensation is very pronounced in both males and females during their second year. It is less pronounced after age 2 in the males, whereas the pattern in the females is similar to that for 4-year-olds, in that the initially fast-growing fish exhibit the largest increment at age 3 and smaller increments for the other ages. Nevertheless, by age 5 growth compensation has virtually eliminated the superiority in length of the fast-growing fish at the end of the first year.

\section{Otolith-body relationships for capelin in other areas}

Because the samples from other localities of the Labrador-Newfoundland region consisted mainly of mature capelin over restricted length ranges, it was not feasible to compare the empirical otolith-body curves for these areas. Instead, ratios of otolith radius to total length of mature fish of each sex were compared (Table 4). As there were no consistent differences in the otolith-body ratios among the various areas, backcalculated lengths at age for capelin from these areas were derived from the empirical curves established for capelin from Trinity Bay (Fig. 4).

\section{Comparison of growth by area}

By utilizing back-calculated lengths at age for each area and sex, von Bertalanffy growth curves were
TABLE 3. Back-calculated growth increments at age for 4- and 5year-old capelin from Trinity Bay, 1967.

\begin{tabular}{|c|c|c|c|c|c|c|}
\hline \multirow{2}{*}{$\begin{array}{c}\text { Age at } \\
\text { capture } \\
(y r)\end{array}$} & \multirow{2}{*}{$\begin{array}{c}\mathrm{l}_{1} \\
(\mathrm{~mm})\end{array}$} & \multicolumn{4}{|c|}{ Length increments $(\mathrm{mm})$ at age } & \multirow{2}{*}{$\begin{array}{c}\text { Final } \\
\text { size } \\
(\mathrm{mm})\end{array}$} \\
\hline & & 2 & 3 & 4 & 5 & \\
\hline \multicolumn{7}{|c|}{ Male } \\
\hline \multirow[t]{5}{*}{4} & 56 & 51 & 35 & 50 & - & 192 \\
\hline & 64 & 49 & 34 & 49 & - & 196 \\
\hline & 72 & 43 & 35 & 48 & - & 198 \\
\hline & 78 & 37 & 40 & 43 & - & 198 \\
\hline & 84 & 39 & 42 & 47 & - & 202 \\
\hline \multirow[t]{5}{*}{5} & 48 & 56 & 30 & 43 & 24 & 201 \\
\hline & 56 & 52 & 28 & 44 & 22 & 202 \\
\hline & 64 & 45 & 27 & 44 & 22 & 202 \\
\hline & 72 & 40 & 27 & 41 & 22 & 202 \\
\hline & 78 & 34 & 26 & 42 & 21 & 201 \\
\hline \multicolumn{7}{|c|}{ Female } \\
\hline \multirow[t]{5}{*}{4} & 56 & 48 & 43 & 30 & - & 177 \\
\hline & 64 & 44 & 46 & 27 & - & 181 \\
\hline & 72 & 37 & 37 & 35 & - & 181 \\
\hline & 78 & 37 & 45 & 23 & - & 183 \\
\hline & 84 & 36 & 54 & 11 & - & 185 \\
\hline \multirow[t]{5}{*}{5} & 56 & 50 & 18 & 44 & 14 & 182 \\
\hline & 64 & 42 & 19 & 43 & 14 & 182 \\
\hline & 72 & 37 & 30 & 35 & 9 & 183 \\
\hline & 78 & 36 & 26 & 40 & 4 & 184 \\
\hline & 84 & 34 & 35 & 28 & 3 & 184 \\
\hline
\end{tabular}

fitted to average length-at-age values by the method of Allen (1966) (Fig. 7). With the esception of Pack's Harbour sample, the asymptotic lengths $\left(L_{\infty}\right)$ correspond fairly well to the maximum lengths of capelin observed in the various areas.

Several patterns of growth are evident from the curves (Fig. 8). Capelin from Trinity Bay, Outer Cove, Grand Bank and Grand Beach, in the southern part of the Labrador-Newfoundland region, exhibit a similar growth pattern, involving fast growth and large average size at age, particularly in fish less than 5 years old. Capelin from eastern Labrador (Pack's Harbour), in the northern part of the region, exhibit slower growth as young fish but an acceleration of growth at later ages to produce as large a maximum size as that indicated for capelin from the Grand Bank and southeastern Newfoundland areas. Capelin from Notre Dame Bay, which is intermediate in geographic location between eastern Labrador and the Grand Bank, exhibit an intermediate growth pattern. The very large disparity in length $(35-40 \mathrm{~mm})$ between fast-growing and slowgrowing fish over age-groups $1-3$ in the different areas is substantially diminished by ages 5 and 6 (approximately $10 \mathrm{~mm}$ ). This is analogous to the growth patterns of the various age-groups in Fig. 6 and may be considered to represent growth compensation between areas.

Length distributions of age 2 immature capelin (Fig. 9) illustrate the increase in size from Davis Inlet to the Avalon Channel (Fig. 1). The difference in size 
TABLE 4. Ratios of otolith radii (EPU) to total lengths $(\mathrm{mm})$ of mature capelin by length group and sex from various localities in the LabradorNewfoundland region.

\begin{tabular}{|c|c|c|c|c|c|c|c|c|c|c|c|c|}
\hline \multirow{2}{*}{$\begin{array}{l}\text { Total } \\
\text { length } \\
(\mathrm{mm})\end{array}$} & \multicolumn{2}{|c|}{ Pack's Harbour } & \multicolumn{2}{|c|}{ Notre Dame Bay } & \multicolumn{2}{|c|}{ Trinity Bay } & \multicolumn{2}{|c|}{ Outer Cove } & \multicolumn{2}{|c|}{ Grand Beach } & \multicolumn{2}{|c|}{ Grand Bank } \\
\hline & M & $\mathrm{F}$ & $M$ & $\mathrm{~F}$ & $M$ & $\mathrm{~F}$ & $M$ & $F$ & $M$ & $F$ & $M$ & $\mathrm{~F}$ \\
\hline 130 & - & - & - & - & - & - & - & - & - & - & 0.169 & 0.168 \\
\hline 135 & - & - & - & - & - & - & - & - & - & 0.166 & - & 0.163 \\
\hline 140 & - & - & - & - & - & - & - & 0.171 & - & 0.163 & 0.162 & 0.168 \\
\hline 145 & - & - & - & - & - & 0.171 & - & 0.166 & - & 0.163 & 0.170 & 0.168 \\
\hline 150 & - & - & 0.160 & 0.162 & - & 0.167 & - & 0.159 & - & 0.165 & 0.163 & 0.167 \\
\hline 155 & - & 0.155 & 0.160 & 0.158 & - & 0.167 & 0.161 & 0.165 & 0.151 & 0.163 & 0.163 & 0.166 \\
\hline 160 & - & 0.158 & 0.155 & 0.159 & - & 0.163 & 0.166 & 0.160 & 0.155 & 0.156 & 0.168 & 0.161 \\
\hline 165 & - & 0.159 & 0.160 & 0.157 & 0.167 & 0.160 & 0.164 & 0.158 & 0.156 & 0.156 & 0.158 & 0.161 \\
\hline 170 & 0.159 & 0.160 & 0.155 & 0.160 & 0.168 & 0.163 & 0.165 & 0.159 & 0.157 & 0.152 & 0.160 & 0.161 \\
\hline 175 & 0.149 & 0.157 & 0.152 & 0.156 & 0.154 & 0.158 & 0.160 & 0.154 & 0.154 & 0.157 & 0.163 & 0.161 \\
\hline 180 & 0.152 & 0.165 & 0.154 & 0.154 & 0.157 & 0.157 & 0.158 & 0.164 & 0.158 & 0.154 & 0.161 & 0.161 \\
\hline 185 & 0.153 & 0.158 & 0.156 & 0.153 & 0.152 & 0.150 & 0.162 & 0.159 & 0.153 & - & 0.159 & 0.155 \\
\hline 190 & 0.151 & 0.155 & 0.151 & 0.150 & 0.151 & 0.153 & 0.158 & 0.154 & 0.154 & - & 0.154 & 0.155 \\
\hline 195 & 0.157 & 0.154 & 0.155 & 0.157 & 0.156 & 0.151 & 0.155 & - & 0.151 & - & 0.156 & - \\
\hline 200 & 0.153 & 0.165 & - & - & 0.154 & 0.153 & 0.159 & - & 0.155 & - & 0.148 & - \\
\hline 205 & 0.150 & 0.154 & - & - & 0.150 & - & 0.151 & - & - & - & 0.156 & - \\
\hline 210 & 0.154 & - & - & - & 0.146 & - & 0.153 & - & - & - & 0.149 & - \\
\hline 215 & 0.151 & - & - & - & 0.149 & - & - & - & - & - & - & - \\
\hline
\end{tabular}

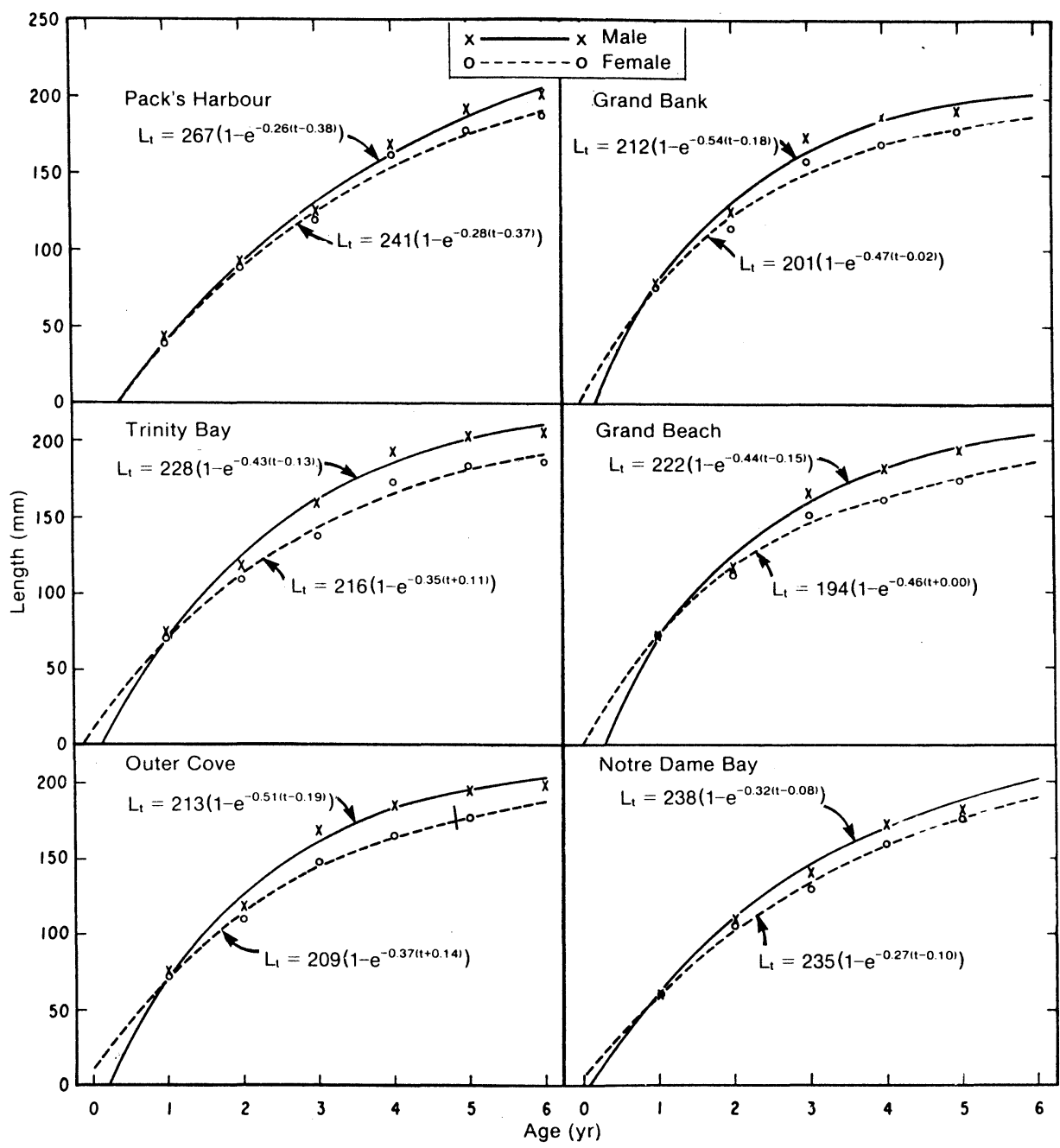

Fig. 7. Growth curves of capelin by sex from various parts of the Labrador-Newfoundland region, fitted to back-calculated length-at-age data by the von Bertalanffy growth equation. 


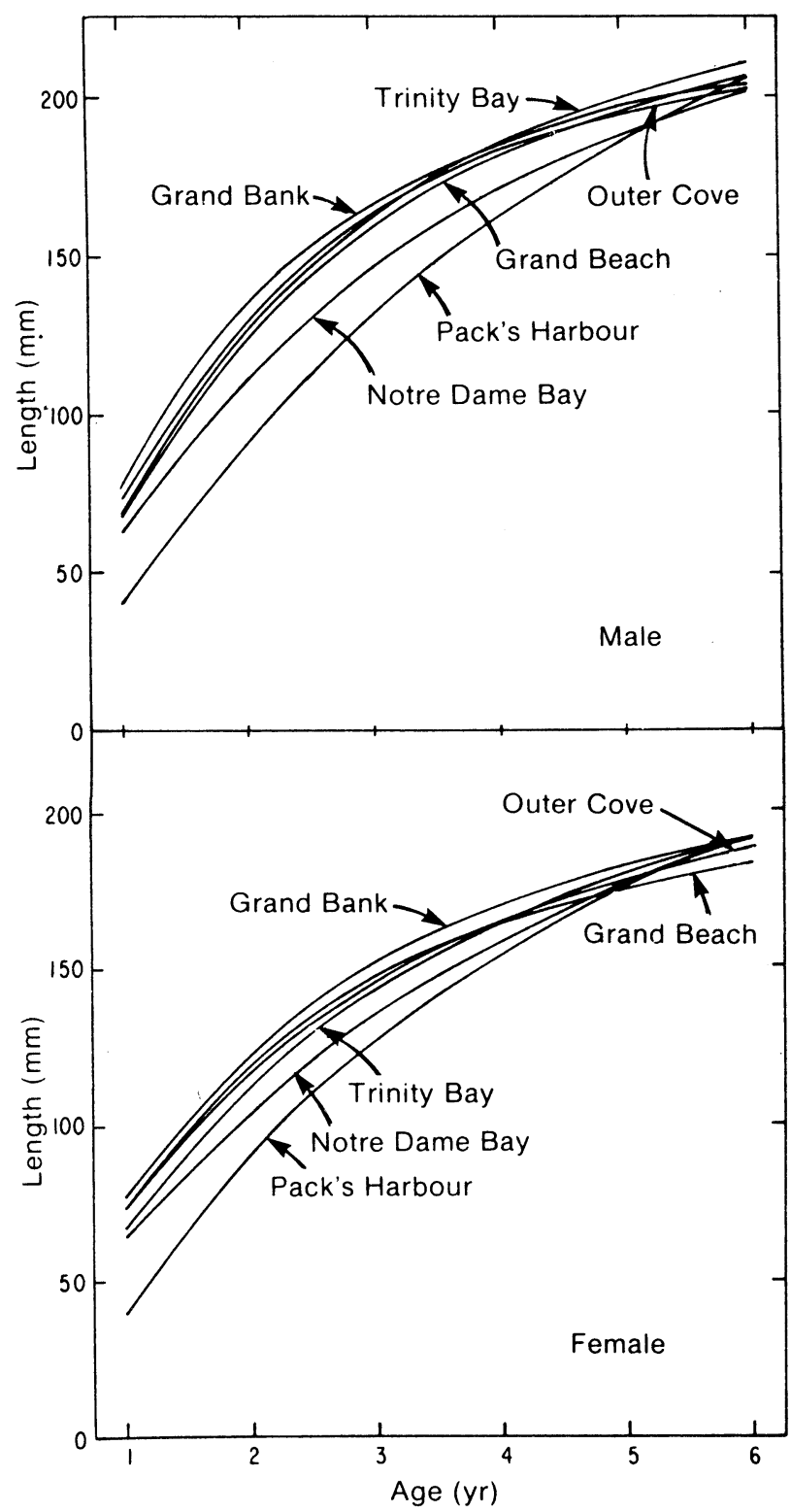

Fig. 8. Comparison of growth curves of capelin by sex from the various parts of the Labrador-Newfoundland region.

between the Davis Inlet and Henley Harbour samples and those from Trinity Bay and Avalon Channel is probably larger than illustrated because of the greater amount of new growth observed in the otoliths of the Labrador capelin which were caught about 1-2 months later. However, there is very little difference at age 5 (Table 9) in the size distributions of Labrador (Pack's Harbour) capelin and those from southeastern Newfoundland.

\section{Discussion and Conclusions}

A gradual change has been demonstrated in the growth pattern of capelin from north to south in the

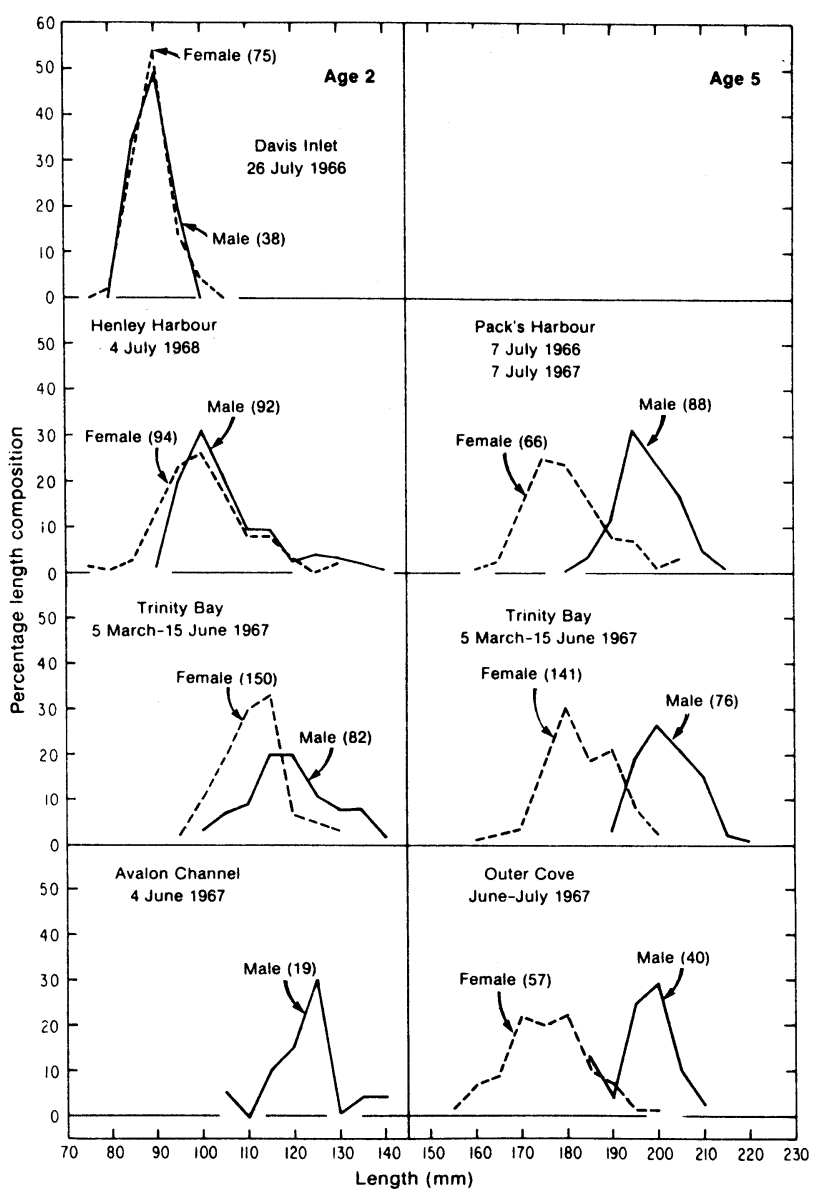

Fig. 9. Length compositions of 2-year-old immature capelin and 5year-old mature capelin, from various parts of the LabradorNewfoundland region.

Labrador-Newfoundland region, i.e. a relatively large final size which is approached rather slowly in the Labrador area, a slightly smaller final size which is approached rapidly in the Grand Bank area, and an intermediate pattern for capelin from Notre Dame Bay. This north-south cline in capelin growth is undoubtedly attributable to the hydrography of the area under consideration. The Labrador Current dominates the temperature regime of the Newfoundland area (Smith et al., 1937; Dunbar, 1951; Bailey and Hachey, 1951; Hachey et al., 1954), and the volume of cold water carried by the Labrador Current declines from north to south (May et al., 1965). Mass beach-spawning of capelin in the region is determined mainly by the availability of suitable temperature conditions, the specific range being from $5.5^{\circ}$ to $8.5^{\circ} \mathrm{C}$ (Templeman, 1948; Winters, MS 1966). In Fortune Bay on the south coast of Newfoundland, such temperatures are generally reached by the first or second week in June (Templeman, 1948). Along the east coast of Newfoundland, beach-spawning usually begins about mid-June in Conception and Trinity Bays and by late June or early July in Notre Dame Bay. Mass beach-spawning in southern Labrador usually does not begin until early 
July and may extend to mid-August (Templeman, 1948), and it may not begin until mid-August in northern Labrador. Recent observations on the Southeast Shoal of the Grand Bank indicate that demersal spawning begins there about mid-June, although Pitt (1958a) reported that spawning occurred there as late as August in 1950. He attributed this late spawning to the unusually cold water over the Southeast Shoal during the summer.

It is evident that the spawning period of capelin begins progressively later from south to north in the Labrador-Newfoundland region, the difference being as much as 1.5 to 2 months over the entire range of the region. This results in a gradual attrition in the duration of the growing period from south to north during the first year of growth, and this is reflected in the progressive decrease in $I_{1}$ values from the southern areas (Grand Bank and Grand Beach) to Labrador (Pack's Harbour) (Fig. 8). For example, the average length of capelin at age 1 was $78 \mathrm{~mm}$ at Grand Beach in contrast to $41 \mathrm{~mm}$ at Pack's Harbour. This disparity in size at age is reflected in the age distributions of mature capelin from various areas (Table 5). Labrador capelin appear to mature about a year later, on the aveage, than Grand Bank capelin and have proportionately fewer mature representatives at younger ages.

In the context of the influence that growth in the early years of life has on subsequent growth, the phenomenon of growth compensation is of special interest in fish, and various explanations for its occurrence as a biological phenomenon have been given in the literature (Watkins, 1927; Runnstrom, 1936; Smith, 1956). According to Zamakhaev (1965), Lee's phenomenon in its typical form may sometimes be regarded as the same thing as growth compensation. Naturally then, in such cases, they will have the same cause.

The occurrence of Lee's phenomenon in capelin is a feature of the life history of the species, particularly with reference to spawning characteristics. The older capelin and the large individuals of a year-class tend to spawn first and, particularly so for males, tend to remain on the spawning grounds for prolonged periods of time (Templeman, 1948). Since capelin suffer high spawning mortality (Winters and Campbell, MS 1974), the greatest mortality would be expected to occur among the older and larger individuals. This is demonstrated by examination of age compositions and mean lengths at age of pre-spawning and postspawning capelin caught on the Grand Bank in June and August 1967 (Table 6), indicating that the survivors of spawning consist mainly of younger and smaller individuals. Prokhorov (MS 1960) found similar results for post-spawning capelin in the Barents Sea. Thus, as a year-class becomes older, the increase in average size of fish becomes less as the proportion of slowgrowing fish increases. Because only a small proportion of capelin mature to spawn at age 2, size-selective mortality would not have a significant effect on this age-group, and both slow-growing and fast-growing individuals would be expected to survive in approximately equal proportions to age 3. This probably accounts for the lack of evidence of Lee's phenomenon at age 2 (Table 2).

Winters (1981) attributed the occurrence of growth compensation in sand lance, Ammodytes dubius, to differing ages at maturity of initially fastgrowing and slow-growing fish. A similar life-history feature may also explain the occurrence of growth compensation in capelin. Capelin which attain a large size at the end of their first year would be expected to mature at an earlier age than the smaller individuals. This is reflected in the larger $I$, values associated with mature 3-year-olds relative to mature 4-year-olds (Fig. 6 ), and similarly with mature 4-year-olds relative to mature 5-year-olds. The spawning process in capelin is associated with cessation of feeding (Templeman, 1948; Winters, 1970) and with deterioration of body condition (Winters, 1970). Consequently, maturation and spawning must result in some retardation of growth. This would eventually enable the initially slowgrowing fish to achieve approximate equality in length with the initially fast-growing fish, resulting in growth compensation as exhibited in Table 3 . This is analogous to the convergence of the growth curves at the

TABLE 5. Age compositions of mature capelin by sex from various localities in the Labrador-Newfoundland region, 1966-67.

\begin{tabular}{|c|c|c|c|c|c|c|c|c|}
\hline \multirow[b]{2}{*}{ Sex } & \multirow[b]{2}{*}{ Locality } & \multicolumn{5}{|c|}{ Age composition (\%) } & \multirow{2}{*}{$\begin{array}{l}\text { Sample } \\
\text { size }\end{array}$} & \multirow{2}{*}{$\begin{array}{c}\text { Mean } \\
\text { age } \\
\text { (yr) }\end{array}$} \\
\hline & & 2 & 3 & 4 & 5 & 6 & & \\
\hline \multirow[t]{4}{*}{$M$} & Pack's Hr & - & 0.6 & 36.3 & 55.0 & 8.1 & 99 & 4.71 \\
\hline & Trinity Bay & - & 19.5 & 62.6 & 17.5 & 0.4 & 334 & 3.99 \\
\hline & Outer Cove & - & 39.3 & 50.6 & 9.3 & 0.8 & 383 & 3.72 \\
\hline & Grand Bank & 0.3 & 65.7 & 31.1 & 3.0 & - & 204 & 3.38 \\
\hline \multirow[t]{4}{*}{$\mathrm{F}$} & Pack's Hr & - & 3.4 & 27.6 & 52.8 & 16.2 & 100 & 4.82 \\
\hline & Trinity Bay & 0.2 & 12.4 & 16.8 & 67.1 & 3.5 & 240 & 4.61 \\
\hline & Outer Cove & 1.2 & 39.4 & 20.7 & 37.1 & 1.6 & 212 & 3.99 \\
\hline & Grand Bank & 1.3 & 49.4 & 30.1 & 17.7 & 1.5 & 202 & 3.69 \\
\hline
\end{tabular}


TABLE 6. Average back-calculated length at age and percentage age composition of mature capelin from the Grand Bank in (A) pre-spawning condition in June 1967 and (B) post-spawning condition in August 1967.

\begin{tabular}{|c|c|c|c|c|c|c|c|c|}
\hline \multirow{3}{*}{$\begin{array}{c}\text { Age at } \\
\text { capture } \\
(y r)\end{array}$} & \multicolumn{4}{|c|}{ Male } & \multicolumn{4}{|c|}{ Female } \\
\hline & \multicolumn{2}{|c|}{ Length (mm) } & \multicolumn{2}{|c|}{ Age composition } & \multicolumn{2}{|c|}{ Length (mm) } & \multicolumn{2}{|c|}{ Age composition } \\
\hline & A & $B$ & A & B & A & $\mathrm{B}$ & $A$ & $\mathrm{~B}$ \\
\hline 2 & 161 & 150 & 0.3 & 27.4 & 133 & 132 & 1.3 & 12.3 \\
\hline 3 & 178 & 172 & 65.7 & 50.0 & 162 & 153 & 49.4 & 72.1 \\
\hline 4 & 191 & 184 & 31.1 & 17.9 & 173 & 166 & 30.1 & 12.3 \\
\hline 5 & 198 & 194 & 3.0 & 3.5 & 180 & 170 & 17.7 & 3.2 \\
\hline 6 & - & 204 & - & 1.2 & - & - & 1.5 & - \\
\hline Sample size & & & 204 & 83 & & & 202 & 156 \\
\hline Mean age (yr) & & & 3.38 & 2.96 & & & 3.69 & 3.09 \\
\hline
\end{tabular}

maximum age (Fig. 8), which may be attributed to the differing ages at maturity of fish from the Grand Bank with large $I_{1}$ values and from Labrador with small $l_{1}$ values. The reversal of growth compensation for agegroups 3 and 4 (Table 2) may be attributed to the possible acceleration of growth in capelin during their maturation year. For example, the growth increment in male 3-year-olds from age 2 to age 3 was $55 \mathrm{~mm}$ for matures but only $29 \mathrm{~mm}$ for immatures (Table 2).

There is some evidence that a portion of the Grand Bank capelin stock move inshore to spawn. Templeman and Fleming (1962) reported that cod, tagged on the northwestern Grand Bank in early June, were recaptured in coastal waters of the Avalon Peninsula in late June during the capelin spawning period. Since these cod were feeding on capelin at the time of tagging, it is likely that they followed the capelin from the Grand Bank to coastal waters. Evidence from acoustic surveys of the Grand Bank (Dragesund and Monstad, 1973) indicates that some of the capelin inhabiting the western and southwestern parts of the Grand Bank also move inshore to spawn. The similarity of growth patterns in capelin from Fortune Bay, Avalon Peninsula and the Grand Bank may therefore reflect such stock relationships.

\section{References}

ALLEN, K. R. 1966. A method of fitting growth curves of the von Bertalanffy type to observed data. J. Fish. Res. Bd. Canada, 23: 163-179.

BAILEY, W. B., and H. B. HACHEY. 1051. The vertical temperature structure of the Labrador Current. Proc. Nova Scotia Inst. Sci., 22(4): 34-48.

BERTALANFFY, L. von. 1938. A quantitative theory of organic growth (enquiries on growth laws. II). Hum. Biol., 10(2): 181-213.

CARSCADDEN, J. E. 1978. The capelin, Mallotus villosus, population spawning on the Southeast Shoal of the Grand Bank, 1976. ICNAF Sel. Papers, 3: 61-71.

CARSCADDEN, J. E., and R. K. MISRA. 1980. Multivariate analysis of meristic characters of capelin (Mallotus villosus) in the Northwest Atlantic. Can. J. Fish. Aquat. Sci., 37: 725-729.

DRAGESUND, O., and T. MONSTAD. 1973. Observations on capelin (Mallotus villosus) in Newfoundland waters. ICNAF Redbook,
1973(III): 127-136.

DUNBAR, M. J. 1951. Eastern Arctic waters. Bull. Fish. Res. Bd. Canada, 88: 1-131.

FRANK, K. T., and W. LEGGETT. 1981. Wind regulation of emergence times and early larval survival in capelin (Mallotus villosus). Can. J. Fish. Aquat. Sci., 38: 215-223.

HACHEY, H. B., F. HERMANN and W. B. BAILEY. 1954. The waters of the ICNAF Convention Area. ICNAF Annu. Proc., 4: 67-102.

JEFFERS, G. W. MS 1931. The life history of the capelin, Mallotus villosus (O. F. Muller). Ph. D. Thesis, Univ. of Toronto, Ontario, Canada, $86 \mathrm{p}$.

MAY, A. W., A. T.PINHORN, R. WELLS, and A. M. FLEMING. 1965. Cod growth and temperature in the Newfoundland area. ICNAF Spec. Publ., 6: 545-555.

MONSTAD, T., and J. GJOSAETER. MS 1977. Growth of the Barents Sea capelin of the year-classes 1967-70. ICES C.M., Doc. No. H:29.

PITT, T. K. 1958a. Age and growth of the capelin (Mallotus villosus) from Newfoundland and Grand Bank areas. J. Fish. Res. Bd. Canada, 15: 295-311.

1958b. Distribution, spawning and racial studies of the capelin (Mallosus villosus 0 in the offshore Newfoundland area. J. Fish. Res. Bd. Canada, 15: 275-293.

PROKHOROV, V. S. MS 1960. Post-spawning survival of the Barents Sea capelin (Mallotus villosus villosus Muller). ICES C.M., Doc. No. 165.

1965. Ecology of the Barents Sea capelin (Mallotus villosus villusus) and prospects for its commercial utilization. Trudy PINRO, 19: 1-70 (Fish. Res. Bd. Canada Transl. Ser., No. 813, 131 p.)

RICKER, W. E. 1969. Effects of size-selective mortality and sampling bias on estimates of growth, mortality, production and yield. $J$. Fish. Res. Bd. Canada, 26: 479-541.

RUNNSTROM, S. 1936. A study on the life history and migration of the Norwegian spring-herring. Rep. Norweg. Fish. Mar. Invest., 5(2), $102 \mathrm{p}$.

SLEGGS, G. F. 1933. Observations upon the economic biology of capelin (Mallotus villosus). Rep. Nfld. Fish. Res. Comm., 1(3), $65 \mathrm{p}$.

SMITH, H. 1956. Life history of the lake herring of Green Bay, Michigan. Fish. Bull., U. S., 57: 87-138.

SMITH, E. H., F. M. SOULE, and O. MOSBY. 1937. The Marion and General Greene expeditions to Davis Strait and Labrador Sea: scientific results, Part 2. Bull. U. S. Coast Guard, 19(2), 259 p.

TEMPLEMAN, W. 1948. The life history of the capelin Mallotus villosus (Muller) in Newfoundland waters. Nfld Gov't Lab. Res. Bull., 17, $151 \mathrm{p}$.

1968. Review of some aspects of capelin biology in the Canadian area of the Northwest Atlantic. ICES Rapp. Proc.-Verb., 158: 41-53.

TEMPLEMAN, W., and A. M. FLEMING. 1962. Cod tagging in the Newfoundland area during 1947 and 1948. J. Fish. Res. Bd. Canada, 19: 445-487.

WATKINS, E. R. 1927. Investigation on Cardigan Bay herring. Rep. Mar and Freshw. Invest., Dept. Zool., Univ. College of Wales, Vol. 
I-II, 1925-1927.

WINTERS, G. H. MS 1966. Contribution to the life history of the capelin, Mallotus villosus, in Newfoundland waters. Fish. Res. Bd. Canada Manu. Rep., No. 870, 56 p.

1970. Biological changes in coastal capelin from the overwintering to the spawning condition. J. Fish. Res. Bd. Canada, 27 2215-2224.

1981. Growth patterns in sand lance, Ammodytes dubius, from the Grand Bank. Can. J. Fish. Aquat. Sci., 38: 841-846.

WINTERS, G. H., and J. S. CAMPBELL. MS 1974. Some biological aspects and population parameters of Grand Bank capelin. ICNAF Res. Doc., No. 76, SDer. No. 3309.

WINTERS, G. H., and J. E. CARSCADDEN. 1978. Review of capelin ecology and estimation of surplus yield from predator dynamics. ICNAF Res. Bull., 13: 21-30.

ZAMAKHAEV, D. F. 1965. On the question of the effect nof growth during the first years of a fish's life on its subsequent growth. $T r$. Vses. Nauchno-lssled. Inst. Morsk. Rybn. Khoz. Okeanogr. (VNIRO), 50: 109-141. (Fish. Res. Bd. Canada Transl. Ser. No. 549 $48 \mathrm{p}$. 